até à data da sua efetivação se o valor depositado não tiver sido corrigido.

$\S 4^{\circ}$ - No caso do parágrafo anterior, se o lançamento for julgado improcedente em decisão administrativa ou judicial definitiva, o valor depositado será devolvido de ofício, até 60 dias após, monetariamente atualizado com bases nos indices a que se refere este artigo".

"Art. $99-\ldots \ldots \ldots$.

$\S 3^{\circ}$ - Se, por falta de quorum, decorrente da ausência de juízes representantes dos contribuintes, o TARF deixar de se reunir por 5 sessões consecutivas, o Secretário da Fazenda poderá avocar o julgamento dos processos pendentes incluídos na pauta das sessões não realizadas, proferindo decisão irrecorrível na esfera administrativa".

"Art. 102 - O presidente do TARF e os juízes representantes dos contribuintes têm direito à gratificacão de $\mathbf{C r} \$$ 120,00 e os juízes representantes da Fazenda à de $\operatorname{Cr} \$ 60,00$ por sessão a que compareçam, até o máximo de 15 sessões por mês".

"Art. 115 - O Secretário da Fazenda, com fundamento na eqüidade e por proposta das autoridades julgadoras ou quando decidir sobre recurso extraordinário, poderá reduzir a multa aplicada em percentagem igual à referida no $\S$ $2^{\circ}$ do art. $7^{\circ}$, atendendo às características pessoais ou materiais do caso, desde que não tenha havido reincidência específica, fraude, conluio ou falsidade.

$\S 1^{\circ}$ - A proposta de que trata o artigo será apreciada antes da intimação da decisão ao sujeito passivo.

$\S 2^{\circ}$ - Do despacho da autoridade julgadora que deixar de encaminhar proposta de aplicação de eqüidade solicitada pelo sujeito passivo, cabe a este, no prazo de 5 dias, contado da intimação, interpor recurso, com efeito suspensivo, ao Secretário da Fazenda, que decidirá a matéria na forma do disposto no "caput" deste artigo".

"Art. 116 - Mediante convênios firmados entre o Estado e os Municípios, as autoridades administrativas estaduais poderão ser incumbidas da apreciação e do julgamento de questões suscitadas entre a Fazenda Pública Municipal e seus contribuintes".

\section{ESTUDOS SOBRE A RESPONSABILIDADE CIVIL DA EMPREASA RODOVIÁRIA DE TRANSPORTE POR DANOS PESSOAIS}

\section{Carlos Eduardo Garcez Baethgen}

Prof. de D. Ind. Civil na UFRGS e na UNISINOS

\section{P R O L O G O}

Não tem este trabalho a pretensão de esgotar os pontos que aborda.

Muito já se disse sobre os tópicos analisados nele e a intenção do autor não é a de repetir, enfadonhamente, as tradições e origens de cada instituto examinado.

Ántes pelo contrário, a intenção é a de trazer algumas sugestões que possam ajudar a atualizar o direito à sociedade atual, completando-se, assim, como um instrumento digno e apto a regrar condutas humanas.

É gasta pelo tempo a frase e a certeza de que o direito acompanha, lentamente, as evoluções sociais regrandoas após, e muito, seu surgimento.

Se isto é verdade e aceitável, não é menos verdade que o desenvolvimento técnico-científico de nossos dias fez com que a sociedade agigantasse seu passo, criando novas condições e novas exigências de vida, fazendo tudo isso com que o cidadão da década de 70 seja absolutamente diferente e com aspiraç̃es totalmente diversas do pacato cidadão da década de 50 .

Nada menos do que 20 anos, o que historicamente é um nada, alteraram profundamente as estruturas sociais de nossa realidade.

Hoje em dia não mais se aceitam certas idéias, tabus e tradições, adotando-se, de outro lado, novas normas de convívio, e já se nota que a geração de 80 será, igualmente diversa e com ambições até antagônicas com as nossas.

Por tudo isso e para tudo isso, é necessário que o di- 
reito mude seu ritmo. Não ao ponto, é verdade, de adiantar-se à sociedade, mas tão somente para ser mais dinâmico, libertando-se de certa rigidez anacrônica e de certos dogmas hoje inadmissíveis, porque bastante ultrapassados.

Não se coloca o assunto, entretanto, em têrmos de alteração absoluta dos padrões jurídicos. O que se visa é que o direito passe a usar, com mais frequiência, métodos que a ciência coloca a seu dispor; que se mantenha uma ciência de cunho profundamente humanístico porque voltado para o homem, porém sem parar no tempo, atualizando-se, a fim de que possa cumprir, em tempos futuros seu papel dentro de uma sociedade cada vez mais dinâmica e exigente.

\section{1 - A RESPONSABILIDADE CIVIL}

\section{CAPITULO I}

\section{HISTÓRICO DA RESPONSABILIDADE CIVIL}

A noção de responsabilidade pelos danos causados a outrém é uma das noçôes que acompanham o homem desde os primórdios de sua evolução.

Embora, é evidente, sem sistematização jurídica nem científica, o fato do dano é sentido como algo destoante de uma certa lógica.

Povos já razoavelmente evoluídos reagiam, não só ao dano causado pelo inimigo, como também achavam razoável a revolta do ofendido ante um dano provocado ou produzido pela ação direta de um companheiro.

Nesta fase, é sabido, a justiça privada era o meio disponivel com que se buscava a composição dos litígios, mas o que cumpre notar é que a repulsa ao dano já era um sentimento atuante nestas sociedades rudimentares.

Assim o mal era reparado pelo mal. Ao ferimento que se sofria, respondia-se com outro ferimento ou até com a morte, que era tolerada pelos componentes estranhos à controvérsia como manifestação justa de equilíbrio social.

Já neste aspecto nota-se que qualquer dano produz, de imediato, um desequilíbrio social. Fôsse permitida a cau sação de danos sem remédios reparadores cairíamos no caos, em pouco tempo.

Entretanto, com a evolução dos homens e da sociedade, a justiça privada, pela imoderação dos meios que representava, já não se tornava mais instrumento eficaz de equilíbrio social, mas revelava a pura e simples preponderância do mais forte sobre o mais fraco. A este desequlíbrio res- ponde a primeira manifestação legislativa neste sentido, a das XII Tábuas, pela aplicação do talião, através do "si membrum rupsit ni eo pacit talio est".

Como resposta à justiça privada o sistema oferecia vantagens, eis que se consertava o desequilíbrio causado pelo to mais forte sobre o mais fraco. Como solucão para o problema é evidente que, em pouco tempo, não mais satisfez.

Qualquer organização societária exige, para seu funcioamento, a preservação de seus componentes. O talião, ao namén eis que sua aplicacontrário, atentava conted a duplicação do problema: a ção representava, na verdade, a duplicação do proporção. A um dano causado seguia-se outro na mesma proporção. A um braço que se imobilizava seguia-se o do ofensor, e com isso a sociedade perdia mais protagonistas na batalha econômica.

Plantado mais este problema não tardou a solução com o que se denominou de período de composição do dano, buscando-se a fórmula de reparar o mal causado.

Passou-se a aplicar uma "pena" ao ofensor, iniciandoPassou-se confusões doutrinárias como mais tarse uma das grandes confusóes doutrinarias como da responsabilidade penal de veremos, com o nascimento da

ao lado da responsabilidade cinha um critério paNo início desta nova era não do dano causado em pena. De outro la a impossível evitar impulsos de vingança através da fórmula do "olho por olho, dente por dente".

Crescia, neste momento, a força da autoridade governamental e aos poucos o assunto vai se submetendo às diretrizes determinadas pelos governantes.

Da composição organizada e pesada pela vítima, passa se a critérios que se vão uniformizando, aos quais se obriga respeito tanto do ofensor como da vítima.

sentindo a sua forca, a autoridade passa a punir não só dano pessoal como também aqueles atos que turbavam a paz social, sem prejuízo pessoal ou com ele, iniciando-se a lenta mas progressiva separação das duas responsabilidades: a penal e a civil.

oferante o Estado pela perturbaão da orđem que seu gesto causava perante a vítima peça dano específico que fazia nascer. Iniciou-se, assim, a lo dano sujeito passivo de certos departicipas, com os crimes de ação pública e os de açâo privada.

Do lado da responsabilidade civil estes movimentos geram o nascimento da "ação de indenização" nos casos em 
que a composição voluntária, entre as partes, não prosperava.

Neste espírito e nessas condições é trazida a lume a con Aquilia" que traz consigo a idéia de responsabilidade por danos causados a terceiros inexistente qualquer pacto ou convenção entre ofensor e vítima, sendo hoje em dia a culpa aquiliana sinônimo de culpa extra-

De início de aplicação restrita aos cidadãos foi, aos poucos, alargando-se a incidência "s cidadãos foi, aos gendo também aos peregrinos, e regulando também ferimentos produzidos em homens livres e danos às coisas er geral. (Originalmente tratava de ferimentos as coisas em e em animais de pasto, bem como do ressarcimento do DAMNUM INJURIA DATUM)

A seguir abrandaram-se as exigências e requisitos de indenização baseada nela, passando, com Justiniano ceder-se ação também para o ressarcimentiniano, a con NON CORPORE DATUM.

Essa, em rápidos traços, a evolução da responsabilidade civil no direito romano, cabendo destaque todo espocial a edição da lei Aquilina, que determinstaque todo espeacontecimentos.

Desta lei surgiu, fundamentalmente, como veremos adiante, a noção ainda muito atuante em que a responsabilidade repousa nassos dias de

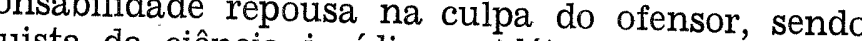
rante da réncia jurídica a idéia, hoje prepondeNo direito francês sem culpa, em certos casos. deste panoram francês, por exemplo, firmou-se, a partir deste panorama, a idéia ferrenha de que responsabilidade culpa sempre deveriam andar juntas, embora já se inia gravidade da culpa não alterava eparação.

A fixação de obrigatoriedade da noção de culpa como requisito de existência de responsabilidade permanece até hoje, mitigada pela evidente realidade contrária mas a prisão e dogmas e tradições jurídicas impedem que se afaste, em definitivo esta idéia, ainda sustentada por autores
de nomeada.

A época de Justiniano os outros povos de formação jurídica evidentemente inferior aos rom vam nas diferenciações de ros engatinhaEntendiam ainda a reparacão do castigo pela prátion uma pena, um

Estes a contrário à ordem.

istes os aspectos que cumpria, a nosso ver, ressaltar evolução da responsabilidade civil. Interessante relembrar que toda a força mobilizadora deste instituto, ligado diretamente à vida social, está na perseguição de um equilíbrio rompido com o dano. O estabelecimento desta noção é fundamental para o desenvolvimento de nossas idéias no desenrolar deste trabalho.

Relembrando, ao desequilíbrio causado pelo dano em si, entenderam os homens restabelece-lo através da aceitação da vingança privada. Deste processo outro desequilíbrio, social mente até de maior peso, qual seja o predomínio do mais forte sobre o mais fraco, desequilíbrio este que provocou nova reação, mesmo porque o desequilíbrio primeiro (causado pelo dano) não desaparecera.

Passou-se, então ao talião, de início com medida apenas da vítima e após medido também pela autoridade, a fim de evitar abusos. Razões de manutenção de ordem social e até de raízes econômicas condenaram o talião e o período de composição segue-se, estabelecendo-se aos poucos um regime de características mais definidas.

Passa então a autoridade a comandar as ações e a ditar as normas, impondo-as tanto a vitimados como a ofensores.

Esta evolução tão rápida no papel é fruto, entretanto, de longos e longos séculos de adaptações de interêsses. Em nossos dias sente-se um desequilíbrio, não mais em têrmos sociais amplos, já que o círculo social alargou-se de tal forma que um fenômeno generalizado é, nestas características, difícil de ocorrer, mas em face a situações concretas restritas, resultante da evolução da responsabilidade civil, dentro de uma espiral dialética, o que será assunto para as próximas páginas.

\section{CAPITULO II}

\section{FUNDAMENTOS DA RESPONSABILIDADE CIVIL}

Como vimos, entretanto, foi grande a convicção dos autores de que a culpa é requisito para a existência de responsabilidade civil.

Até nossos dias permanecem vigorando certos dispositivos que exigem a culpa para a caracterização de responsabilidade.

Já se viu que o elemento dinâmico que gerou toda a cadeia de instituicões que culminou na responsabilidade civil é o desequilíbrio social gerado pelo dano em si.

A culpa como requisito da responsabilidade esbarra, des- 
de logo, nos casos de responsabilidade por fatos de coisas ou de animais, ou ainda, por atos de incapazes. Nestes ca sos torna-se bem mais difícil a inserção do conceito de cul pa para justificar e fundamentar a responsabilidade.

Entretanto, os adeptos da teoria da culpa, mesmo assim, procuram encontrar em todos estes atos manifestações de vontade do responsável que encerrariam algum resquício de culpa, sendo grande espada neste sentido a "culpa in vigilando" e a "culpa in eligendo".

A teoria de culpa chega ao épice com a afirmativa de VON IHERING: "sem culpa nenhuma reparação" (1).

Ante a desencadeada idéia de que a culpa era requisito para existência de responsabilidade, pesquisou-se no sentido de descobrir se, no direito romano, já estava assim tão presente a idéia de culpa, e concluíram os MAZEAUD que somente no fim da República é que ganhou sentido a culpa aquiliana, sendo antes muito precária a sua noção entre os romanos.

Em nossos dias permanece acesa a disputa entre a teoria da culpa e a chamada teoria do risco, para caracterização do verdadeiro fundamento da responsabilidade civil.

Evidentemente que ambas correntes já se apresentam principalmente a primeira, despidas daqueles dogmas que vigoraram durante tanto tempo.

$\mathrm{Na}$ verdade, a tendência é pela adoção de critérios mais flexíveis, que permitem que novos fatos sociais sejam aceitos e regulados dentro de condições doutrinárias mais favoráveis, sob pena de incidirmos no mesmo camos, ou seja, a estagnação do direito diante de uma realidade determinada, sem condições de acompanhar a evolucão daquele fato

De nada nos adiantaria a fixação de critérios, embora perfeitos, para nossa realidade atual, rígido que se auto-destruíriam em pouco tempo.

As posições das pessoas em face ao dano e ao desequilíbrio que ele gera alteram-se as condições sociais em que , na mesma medida em que ra. Se não há um condicionamento absolut fendemos é egável a influência do cenário social sobre concepção individual.

Assim, antes de formular idéias sobre o fundamento da responsabilidade civil, é de alertar do perigo da posição dog

(1) VON IHERING, Schulnmoment, pag. 50, apud Pontes de Miranda, in José de A. Dias "Da Responsabilidade Civil" pag. 48, a a M mática absoluta, como impecilho de desenvolvimento do próprio direito.

Mas, exige a ciência jurídica a explicação e a fundamentação de cada fenômeno normativo.

Os seguidores da teoria da culpa, a princípio absolutos e intransigentes, diante de certos fatos sociais que passaram a ocorrer com maior freqüência, foram forçados a revisar suas posições e partir para soluções técnico-Legislativas, ainda hoje vigentes, inclusive no Brasil como adiante veremos, a fim de salvar a teoria da culpa que ameaça naufragar ante a torrente.

A solução mais exitosa foi a instituição da culpa presumida, através da qual retira-se da vítima o pesado encargo de provar a culpa do ofensor.

Em nossos dias, os tribunais brasileiros fundamentam vários acórdãos nesta presunção de culpa, entendendo-a patrocinada por dispositivo legal, no caso de transporte de pessoas o art. 17 da lei $n^{\circ} 2.681$ de 7 de dezembro de 1912, que regula a responsabilidade civil das estradas de ferro.

Tem-se assim, ainda, como fundamento do dever de indenizar, a culpa porém uma culpa toda especial qual seja a presumida. Esta presunção se não é "de jure" somente admite prova, em contrário na hipótese de caso fortuito ou culpa do viajante.

Com isso contorna-se uma das maiores dificuldades que a teoria da culpa ocasionava, ou seja, a quase impossibilidade do ofendido de demonstrar em juízo a responsabilidade do ofensor, eis que tinha de suportar o ônus probatório da culpa pelo dano.

Mesmo com a presuncão da culpa não se conseguiu afastar todos os problemas, tendo sido ingente a tarefa da jurisprudência em regulamentar a matéria, parca de disposições legais.

Em outros aspectos teve de se socorrer de conceitos pouco claros e imprecisos, tais como a "culpa in vigilando" e "in eligendo".

Assim em atos de incapazes ou fatos de animais, ante até o desconhecimento dos atos ou dos fatos pelo respon sável civil, trazia-se o mesmo através destas duas formas de culpa.

Esta solução, entretanto, tecnicamente, não soluciona problemas mais modernos, como é o caso, por exemplo, da responsabilidade civil da emprêsa de transporte por acidentes causados por seus prepostos. Aplicando-se, como fundamento, a "culpa in eligendo" admite-se a prova em contrário e toda a emprêsa moderna, na escolha de seus motoris- 
tas, age com evidente cuidado e esmero, isentando-se a partir daquele raciocínio da responsabilidade, eis que não haveria forma de fundamentá-la. solução.

Ora, a realidade atual não se pode satisfazer com esta

A idéia de culpa "in vigilando" e "in eligendo" tem é evidente, suas aplicações, mas o seu uso exagerado para explicar todos os fenômenos em que não há participação direta do responsável, não pode ser admitido como construção teórica de um instituto.

SALEILLES inicia, a partir da constatação desta reali dade, uma reação que traz como idéia básica a verifica ção de que a culpa não pode ser considerada indispensável para a fundamentação da responsabilidade civil.

Pode-se inferir até que a teoria da culpa nasceu e se desenvolveu dentro de um espírito de confusão entre a res ponsabilidade civil e a penal.

O respeitável autor frances procura sanar este vício entendendo de se alterar a proposição inicial. Do "quem é o responsável", deve-se partir para "quem deve reparar o dano?" afastando todo e qualquer resquício de identidade en tre as duas responsabilidades.

Realmente se nos afigura correta a ponderação de SA LEILLES. A indagação de quem é o responsável traz dentro de si a preocupação com o causador do dano, ao passo que só perquirição de quem será o reparador do mesmo ajuda a afastar a noção exagerada de culpa e ajuda a responder a indagação básica da responsabilidade.

Segundo José de A. Dias nasceu a teoria do risco com a preocupação de THOMASIUS em explicar a responsabilidade pelos atos de incapazes, a quem não se poderia denominar de culpados(2).

Vários autores, a partir da sucumbência da teoria da culpa, procuraram sistematizar uma nova fundamentacãa do dever de indenizar, baseando-se no risco, sob diferentes enfoques.

Uns entendiam que a exploração normal de um negócio já é fundamento suficiente para fazer com que o titular do mesmo arque com os danos que ele ou seus prepostos causem a terceiros, seja através da execução de contratos derivados da exploração do negócio, seja através das relações extra-contratuais.

Com isso deixava-se a preocupação da existência ou não de culpa do negociante para um segundo plano, ou seja,

(2) José de A. Dias, ob. cit., pág. 57 para o caso da participação de terceiros no dano e a competente ação regressiva.

Assim, mesmo sem culpa, responde o negociante pelos riscos que o seu negócio traz em si, indenizando o lesado, somente pelo fato de expo-lo ao risco, independente de aspecto subjetivo, qual seja a perquirição de culpa.

Outros entendiam como solução o fato de examinarse a situação econômica dos participantes da relação em que surgiu o dano. Assim, se é de posses o ofensor deve responder pelo dano, ao passo que invertendo-se as figuras, teríamos a exoneração do ofensor de poucas posses.

Esta corrente, preocupada com o desequilíbrio social posterior à Revolucão Industrial, esquece e confunde elementos, a nosso ver totalmente distintos. Pouco importa, para a fundamentação do instituto, a situação econômica das partes envolvidas. Poderá ela ter alguma repercussão na fixação da quantia indenizatória, mas nunca no plano de procura do responsável.

Os expoentes da teoria do risco foram, indubitavelmente, ADOLF e RUDOLF MERKEL.

Várias outras feições tomou a teoria do risco, sendo que esta primeira é a de maior importância.

Como reação ao que se denominou o exagerado risco, surgiram correntes conciliatórias procurando unir as duas teorias, tentando dar uma idéia mais flexível do fundamento da responsabilidade.

DEMOGUE entendia que a utilização da teoria do risco somente deveria ocorrer quando o negociante usasse o que denominou de agentes perigosos.

Desde logo surge a dúvida: o que será elemento ou agente perigoso? Em princípio todo o agente que cause dano a terceiros é perigoso e assim a aplicação da teoria do risco seria absoluta.

SAVATIER entende que culpa e risco são ambos fundamentos de institutos diferentes, cada um fundamentando o seu. Assim a responsabilidade por culpa seria outra coisa diferente da responsabilidade sem culpa. Parece-nos uma idéia que embora não totalmente absurda, eis que há responsabilidade fundada na culpa e responsabilidade sem culpa, não enfrenta o problema fugindo do mesmo.

Se algo pode apresentar mais de um aspecto, pode permitir mais de um enfoque, nem porisso terá natureza diversa. Fundado na culpa ou fundado no risco o que há é o dever de indenizar, que é um só, uno e lógico em si mesmo. 
Em nossos dias a tendência pende para a teoria do risco, mais pelo fato de livrar-se do fantasma da culpa absoluta do que por méritos flagrantes seus.

Livres, entretanto, do domínio absoluto da culpa, não raro os juristas de hoje voltam a preocupar-se com ela. Já assente a desnecessidade da culpa para a existência da responsabilidade, custem as legislações a adotar tal idéia. Tímidas manifestações de quando em quando confortam ao desenvolvimento da ciência do direito.

$\mathrm{Na}$ verdade, em nossos dias, não se pode permanecer estagnado ante a idéia da culpa. O ritmo trepidante de nossos dias não admite mais indagacões filosóficas a respeito da fundamentação perfeita do instituto. Ocorrido o dano o desequilíbrio social daí resultante exige a reparação. Há casos em que a culpa é flagrante e não há maiores dificuldades. Há casos, entretanto, em que a procura de alguma culpa, mesmo com as soluções que vimos adotadas pelos seguidores da teoria da culpa, atrasem o processo da reparação, e estes justamente são os aspectos incompatíveis com a realidade de nossos dias.

Um desequilíbrio precisa ser sanado. A solução deve ser rápida e eficiente, mas deve haver o cuidado de não se causar, em certas áreas, outros desequilíbrios tão rigorosos como o causado pelo dano.

\section{CAPITULO III}

\section{O CONTRATO DE TRANSPORTE - EXISTENCIA E VALIDADE}

O terreno mais fértil para a aplicação da responsabilidade civil é, indubitavelmente, o transporte que em nossos dias, com o desenvolvimento nesta área oferece os melhores casos para exame.

Neste campo encontram-se, em primeiro lugar, emprêsas organizadas e desenvolvidas para o fim de transportar pessoas ou cargas, sejam emprêsas rodo-ferroviárias, aéreas ou marítimas.

Neste campo encontram-se com óbvia maior freqüência os casos de acidente, resultando lesões e perdas, ocasionando assim problemas de responsabilidade civil.

Aparecem nitidamente as responsabilidades contratuais e as extra-contratuais, as primeiras relativas às responsabilidades com os passageiros ou mercadorias transportadas $\mathrm{e}$ as segundas relativas às responsabilidades por danos causados a terceiros, alheios ao contrato de transporte em si.
Cumpre, por isso, estudar, como primeiro passo, o contrato de transporte, e sua existência e os casos de nulidade do mesmo, com seu reflexo no problema de responsabilidade civil.

A definição de contrato de transporte é singela e não oferece maiores dificuldades. O próprio anteprojeto do Código Civil, ora em estudos, oferece, no seu art. 741 uma definição simples e correta:

"Pelo contrato de transporte alguém se obriga, mediante retribuição, a transportar, de um lugar para outro pessoas ou coisas".

Portanto, no contrato de transporte uma das partes se obriga a transportar e outra a pagar o preço da passagem ou do frete.

$\mathrm{Na}$ obrigação de transportar tem-se entendido incluída a cláusula de transportar com incolumidade, ou seja, a obrigação de fazer com que o passageiro chegue são e salvo a seu lugar de destino, bem como a obrigação de fazer a pessoa transportada chegar no local de destino na hora previamente estipulada.

Cogita, inclusive, o anteprojeto do Código Civil da responsabilidade civil pelo descumprimento desta cláusula de horário, exonerando-se apenas em caso de prova de força maior. evidente que, neste caso, o passageiro deve provar o dano que alega ter sofrido, em razão do atraso ou do adiamento na chegada ou na partida.

Um aspecto que desde logo chama a atenção em relacão ao contrato de transporte, é o transporte gratuito, muito comum em nosso meio.

Se o pagamento do preço da passagem é a obrigação principal do passageiro ou do credor do contrato de transporte, se alguém não paga, se é conduzido de favor, há ou não há contrato de transporte?

$\mathrm{Na}$ falta de qualquer disposição legal em respeito a esta matéria é de observar o que dispõe o anteprojeto do Código Civil:

"Art. 745 - Não se subordina às normas do contrato de transporte o feito gratuitamente, por amizade ou cortesia.

Parágrafo único: Não se considera gratuito o transporte quando, embora feito sem remuneração o condutor auferir vantagens indiretas". 
Realmente, faltando uma das contraprestações básicas - pagamento do preço - não se pode cogitar de negócio jurídico bilateral funcional. Contrato stricto sensu não há.

Porém, é evidente que o transportador deverá zelar pela incolumidade do passageiro, haja ou não contrato de transporte. Não se poderia admitir que, em face da inexistência do contrato pudesse 0 transportador esquecer o aspecto de segurança no transporte.

De outro lado, poderíamos imaginar aspectos de nulidade no contrato de transporte. Exemplo: um absolutamente incapaz contrata com o transportador seu transporte, sem representação de ninguém ou sem mesmo o conhecimento de seu responsável.

Ficaríamos ante um dilema: ou abrigaríamos uma grave exceção no regime de nulidade do direito civil, admitindo a validade de um contrato celebrado por absolutamente incapaz, ou teríamos de admitir que aquele ato contrato não foi. Entendemos que se trata, na espécie, de um ato-fato, ou seja, um ato que entrou no mundo jurídico como mero fato.

Do ponto de vista da responsabilidade civil: há obrigação de conduzir com incolumidade?

E evidente que há. A incolumidade não pode ser encarada como objeto do contrato. As partes não dispõe sobre ela, eis que se admitirmos isto, teríamos que admitir que as partes poderiam dispor diferentemente, e não podem, é evidente.

Portanto, a obrigação de transportar nasce com o contrato. O transportador pode recusar transportar gratuitamente, bem como pode recusar transportar o absolutamente incapaz sem representação. Porém a obrigação de transportar com incolumidade nasce, pura e simplesmente, do fato do transporte; nasce no momento em que qualquer pessoa adentra o veículo, ocasião em que se submete a todas as medidas de seguranca que o transportador determinar.

Outro exemplo da inexistência de contrato de transporte é o fato de, por exemplo, o fiscal do poder concedente que, em serviço, embarca num veículo. Não há dever de transportar com incolumidade? Há e é evidente que não há contrato.

Portanto, em nosso ver, a obrigação de transportar com incolumidade nasce do próprio fato do transporte e o dever de indenizar decorrente do descumprimento desta obrigação pode ter origem contratual, bem como pode ter origem extra contratual.
Em nosso entender, do fato de transporte nasce, para o transportador o dever de indenizar os danos sofridos por seus passageiros, independentemente de culpa sua.

E importante situar que a possibilidade desta responsabilidade contratual ou extra-contratual, como dever de reparar independentemente de culpa só se pode aplicar aos passageiros do veículo.

Se a vítima é terceiro, fora do âmbito de ação do transportador, portanto fora daquela área de subordinação do transportador, só se pode reger a responsabilidade civil pelo sistema da culpa, eis que não havia em relação a ele qualquer relação de proteção e a obrigação de não causar danos não é a especial de que goza o passageiro, independente de haver contrato de transporte ou não, mas a comum do "naeminem laedere".

Resumindo nossa idéia, podemos dizer que afastada a preocupacão de caracterizar contrato de transporte ou não, sua validade ou nulidade, em relação ao passageiro, tem transportador responsabilidade sem culpa, ao passo que em relação a terceiros sua responsabilidade somente pode se originar de culpa, admitindo-se até, em função de disposições legais, e da projeção cada vez maior da teoria do risco, a presunção de culpa.

Assim, no primeiro caso não se admitiria siquer a prova em contrário da existência de culpa, eis que dela não se cogita. No segundo caso, entretanto, é de se admitir a prova da existência de culpa, eis que é ela, requisito para a existência da responsabilidade.

Fica ressalvada a possibilidade de acão regressiva contra o terceiro causador do dano em ambas as situações, bem como a possibilidade de a vítima acionar diretamente ao terceiro que entende o responsável pelo dano.

Trata-se de medida de dinamismo do direito, de apressamento de soluções, embora como vimos alertando desde o início há que tomar cuidado com outro tipo de desequilíbrio que se forma, e que se estudará adiante.

A responsabilidade sem culpa do transportador não poderá ser medida isolada. A tendência, já se vê é a adoção da teoria do risco indistintamente a todo ofendido, passageiro ou não, porém isto só se poderá aceitar num estágio mais evoluído da responsabilidade civil, estágio este já aceito em diversas legislações e mesmo na brasileira, em relação a transporte específico como o aéreo. 


\section{CAPITULO IV}

\section{RESPONSABILIDADE CONTRATUAL}

\section{E EXTRA-CONTRATUAL}

Costumeira a distinção que se faz entre responsabilidade contratual e extra-contratual.

No caso de transporte de pessoas, contratual seria a responsabilidade do transportador perante o passageiro regular. Extra-contratual seria a responsabilidade do mesmo perante terceiros vítimas de um dano, mas estranhos à relação de transporte.

Em relação aos casos que examinamos no capítulo anterior, teríamos uma dúvida.

Em caso de inexistência do contrato de transporte (transporte gratuito ou fiscalização) e mesmo no caso da nulidade do contrato de transporte (contrato celebrado por incapaz absoluto) teríamos a primeira dificuldade em caracterizar a responsabilidade do transportador.

Se contratual não poderia ser no caso de inexistência do contrato, poder-se-ia cogitar dela em caso de nuliadde do contrato?

Abrir-se-ia, a partir deste momento franca discussão, eis que a natureza de contrato ou de ato-fato neste tipo de relação é assunto controverso na doutrina. peito.

Entretanto, cumpre esclarecer nossa posição a este res-

Entendemos correta a classificação da responsabilidade em contratual e extra-contratual apenas em face a origem da responsabilidade e não em face ao seu fundamento.

A responsabilidade que nasce do contrato é a mesma que nasce extra-contratualmente, ou do ato ilícito.

Nosso Código Civil regulou separadamente as duas responsabilidades, porém entendemos que as soluções práticas para ambos os casos não podem ser divorciadas, nem obedecem a princípios diversos.

Tanto num caso como no outro a responsabilidade é a mesma.

A distinção que fizemos no capítulo III, in fine, referese a outro fato, que não a existência ou inexistência de contrato. Referia-se ela ao fato do transporte da vítima independentemente de verificação da existência de contrato entre ela e o transportador.

Adotávamos para os casos de danos as pessoas transportadas a idéia de que a subordinação às determinações do transportador, em matéria de segurança de transporte, eram elemento determinante da aplicação direta da teoria do risco fundamentando-se a responsabilidade do transportador neste fato apenas.

De outro lado, não era a inexistência de contrato de transporte que determinava que a responsabilidade do transportador, perante vítimas não transportadas se fundamentasse na existência de culpa, mesmo presumida: era a sua não subordinação à esfera de poder do transportador.

Portanto, a nosso ver, a distincão entre responsabilidade contratual e extra-contratual tem apenas a finalidade determinativa da origem da mesma, não alterando em nada as suas conseqüências.

\section{CAPITULO V}

\section{DISPOSICÕES LEGAIS BRASILEIRAS SOBRE RESPONSABILIDADE EM TRANSPORTE DE PESSOAS}

Como sabemos o transporte coletivo de pessoas poderá ocorrer via ferroviária, aérea, marítima ou rodoviária.

Apenas o transporte rodoviário de pessoas não está regido diretamente por nenhum dispositivo legal com relação a responsabilidade civil.

Analisemos os principais dispositivos reguladores da matéria:

(a) - Lei $\mathrm{n}^{\circ} 2.681$ de $\mathrm{y}$ de dezembro de 1912 - Regula a responsabilidade civil das estradas de ferro.

Este é o primeiro dispositivo legal brasileiro que regularmenta, especificamente, a responsabilidade civil em matéria de transporte de pessoas.

O Código Comercial, em seu art. 102 regulara, anteriormente a responsabilidade civil do transportador marítimo por danos e avarias nas mercadorias transportadas.

A lei 2.681 inicia por regular as responsabilidades do transportador ferroviário em relação às mercadorias, e a partir do art. 17 regula a responsabilidade civil do transportador em caso de danos às pessoas transportadas.

Diz ele:

"Art. 17 - As estradas de ferro responderão pelos desastres que em suas linhas sucederam ao viajante e de que resulta a morte, ferimento ou lesão corpórea. 
A culpa será sempre presumida, só se admitindo em contrário alguma das seguintes provas: I - caso fortuito ou força maior;

II - culpa do viajante não concorrendo culpa da estrada".

Vê-se desde logo que este dispositivo legal, editado em 1912, antes do Código Civil e antes das ponderacóes de conceituados doutrinadores, sentindo as dificuldades enormes apontadas e conseqüências da aplicação direta e absoluta da teoria da culpa, tenta contorná-las, fazendo inverter o ônus da prova através da presunção da culpa.

Hoje tal sistema é, em nosso entendimento, anacrônico quando o estende ao "viajante" entendendo-se aí o credor de um contrato de transporte válido. Mas à sua época foi um extraordinário avanço que aliás explica a sua vigência e aplicação até nossos dias. O sistema de presumir a culpa é quase a adoção da teoria do risco. Não o é por pequena exceção, quando se permite a prova de caso fortuito ou força maior, abrindo uma discussão acesa para a conceituação desta figura, ante a casuística do dia a dia.

Quanto a permissão de prova de culpa exclusiva da vítima, entendemos que mesmo a teoria do risco admite-a, eis que ninguém se pode beneficiar de algo que praticou, o que traduziria uma iniquidade absoluta.

Se a vítima causou seu próprio dano não há que se cogitar de responsabilidade do transportador, caindo por terra em conseqüência a busca de sua fundamentação.

Como diziamos, este artigo entrava a rápida obtenção dos remédios legais justamente pela possibilidade de permitir a prova do caso fortuito ou da força maior.

Vários e vários exemplos estão a demonstrar o erro desta permissão. São variados os casos de responsáveis que tentam exonerar-se alegando os mais imaginosos casos de força maior como defeitos imprevisíveis nos veículos e outros fatos.

Entendemos que, justamente estes fatos constituem o somatório de riscos a que está sujeito o transportador.

Portanto, louvemos este dispositivo legal como precursor de uma nova idade de responsabilidade civil no Brasil. Apenas fazemos nossa crítica ao que entendemos o entravamento das soluções para as demandas nesta matéria.

A adoção da teoria do risco, com a única exceção quanto à causação do dano pela própria vítima, parece-nos a medida mais adequada para a solução dos problemas nesta

\section{(b) - O Código Brasileiro do Ar. Decreto-Lei $n^{\circ} 32$ de 18 -} 11-1966

O Código Brasileiro do Ar, concorde com convenções internacionais a respeito, no tocante à responsabilidade civil, adota integralmente a teoria do risco, em relação as passageiros.

Assim dispõe no seu art. 97:

"O transportador responde por qualquer dano resultante de acidente relacionado com a aeronave em vôo, ou na superfície, a seu bordo ou em operação de embarque ou desembarque, que causar a morte ou lesão corporal do passageiro, salvo culpa deste, sem culpabilidade do transportador ou de seus prepostos".

Vê-se aqui, nitidamente, que independe a procura de culpabilidade ou não do transportador: assume ele os riscos do transporte, da atividade negocial que explora. Excetua-se apenas a culpa exclusiva do dano pela própria vítima, o que é curial.

Inexplicavelmente, em nosso ver, a disposição seguinte do parágrafo único do mesmo artigo; representa a volta ao problema que já havia sido sanado:

"Parágrafo único: No transporte gratuito a responsabilidade dependerá de prova, a cargo da vítima ou de seus beneficiários, de dolo ou de culpa do transportador ou de seus prepostos, ressalvado o direito à indenização do seguro contratado sem exclusão do passageiro gratuito".

Volta-se, repentinamente, ao sistema da culpa, com todos os seus problemas e indefinições, e a única diferença entre os dois casos é a existência ou não de contrato de transporte, distinção esta que, a nosso ver, não pode alterar substancialmente uma situação idêntica em sua realidade objetiva. $\mathrm{e}$ o mesmo que dizer que a incolumidade, ou melhor, o ser transportado com incolumidade é prerrogativa do que firma um contrato de transporte, eis que a prova exigida de dolo ou culpa do transportador aéreo é difícil senão impossível, de ser obtida, em razão das proporções que geralmente assumem tais acidentes.

No tocante à responsabilidade perante terceiros, aqui entendido o não transportado, o sistema adotado pelo Código Brasileiro do Ar é "sui generis".

Inicia-se por adotar, novamente, a responsabilidade sem culpa, excepcionando-se, entretanto, no parágrafo imediato, que não será indenizável o dano causado em virtude de ope- 
ração normal de aeronave, de acôrdo com as normas regulamentares. Trata-se do art. 110:

"Dará direito à reparação qualquer dano que a aeronave causar a pessoas ou bens no solo ou em água jurisdicionaîs brasileiras, bem assim originado por pessoas ou coisas dela caídas ou pro jetadas, inclusive pelos alijamentos de forca maior.

Parágrafo primeiro: Não dará direito, entretanto, à reparação o dano que não for conseqüência direta do fato causador ou que consequenvirtude de operação normal da aeronave, realizada de conformidade com as normas recomendadas".

Não é admissível esta exceção. Não podemos concordar em tese, com a extensão de teoria do risco e terceiros não transportados sem a cláusula limitativa da responsabilidade, porém concordamos menos ainda com a quebra absoluta do sistema, quando se adota a teoria do risco em absolugorismo máximo e após se abre uma exceção que diz exatamente o contrário, ou seja, que o dano causado por atividade normal de aeronave não é indenizável: o mesmo que dizer que quem suporta os riscos da atividade é que vê, por exemplo, sua plantação ser destruída pelo combustível lançado ao ar pela aeronave, se esta operação era normal segundo as regras técnicas de aviação. Não podemos entender este dispositivo que foge a qualquer apreciação sistemática.

Grande avanço, entretanto, representa o art. 103 que, tratando da responsabilidade em relação ao passageiro, limita o "quantum" da indenização.

Desde o início desta obra vimos alertando para o perigo de manter o equilíbrio desfeito pelo dano a custa de outro desequilíbrio. É o que evita o Código Brasileiro do $\mathrm{Ar}$ neste artigo, quando estabelece o limite para a pretensão do autor.

Veremos em capítulos posteriores, com maiores detaihes, este aspecto.

Este limite é tornado sem efeito quando aja com dolo o transportador ou seus prepostos, o que é correto, eis que não se poderia entender o estabelecimento deste limite no caso de haver tido o autor a intenção premeditada de cau sar o dano.

Estas, em rápida análise, as disposições legais de maior significação dentro do ordenamento jurídico brasileiro em relação à responsabilidade civil em matéria de transporte coletivo de pessoas.
Como se vê o legislador adotou, em relação ao transporte ferroviário, a teoria da culpa como regra invertendo o ônus da prova, e assim, tornando a presunção de culpa quase inarredável. Não teve coragem, na época, de adotar totalmente a teoria do risco.

Já o Código Brasileiro do Ar tomou esta iniciativa, consagrando a teoria do risco, abrindo, entrementes, inexplicáveis falhas em relação a aspectos consequentes da aplicação desta teoria, como examinamos.

A fixação de limite para as emprêsas aéreas, em nossa opinião, é o mais importante passo para a definição correta do assunto, eis que evita aquele outro desequlíbrio a que tanto nos referimos.

\section{(c) - $\mathrm{O}$ anteprojeto do Código Civil}

No Título IX trata o anteprojeto do Código Civil da responsabilidade, e logo no primeiro artigo examina e regula a matéria (art. 986) traçando uma norma que merece exame mais detido:

"Art. 986: Aquele que, por ato ilícito causar dano a outrém é obrigado a repará-lo.

Parágrafo único - Todavia haverá a obrigação de reparar o dano, independentemente de culpa, nos casos especificados em lei, ou quando a atividade normalmente desenvolvida pelo autor do dano implicar, por sua natureza, grande riscos para os direitos de outrém, salvo se comprovado o emprego de medidas preventivas tecnicamente adequadas".

Tenta o legislador adotar o critério da responsabilidade sem culpa, aplicando a teoria do risco. Entretanto entendemos falha a redução deste dispositivo.

Em primeiro lugar abrir-se-á enorme discussão para caracterizar os "grandes riscos", o que sempre determina entraves judiciais e ingentes esforços jurisprudenciais para amenizar, através de critérios, os debates protelatórios a respeito.

De outro lado, não menos saudável é a exceção que se abre afinal, qual seja a de exonerar o responsável pelo dano quando for comprovado o emprego de medidas preventivas adequadas tecnicamente.

Em princípio, novamente a discussão sobre o que se entender por "medidas preventivas tecnicamente adequadas", mas principalmente pela instauração de enorme dú- 
vida quanto a reparação do dano, nos casos em que o responsável adotar tais medidas.

Apenas como exmplo: provado que a sua equipe de manutenção é excelente e que todas as medidas preventivas foram adequadamente tomadas, exonerar-se-ia o transportador da responsabilidade por acidente cuja causa fosse de feito do veículo.

Não será transferir ao passageiro o risco?

Com estes comentários entendemos ter destacado o que de mais importante há em têrmos de responsabilidade ci vil em transporte de pessoas, na área legislativa.

\section{CAPITULO VI}

\section{A TAREFA DA JURISPRUDENCIA E SUAS CONCLUSõES}

Como já salientamos, o transporte rodoviário de pessoas não foi contemplado com uma regulamentação própria.

Adiante termos série de dados que informam do extraordinário relevo que este tipo de transporte possui, em nossos dias, no Brasil.

Assim, um sem número de casos do dia a dia aparecem nos tribunais, reclamando uma providência.

Com isso ganhou a tarefa jurisprudencial, neste aspecto, uma conotação quase de fonte direta do direito, tendo de criar normas para regrar uma dada situação de fato.

$\mathrm{E}$, como era de esperar, desempenhou-se airosamente. A primeira grande conquista jurisprudencial, neste tema foi a extensão da lei 2.681 a outros transportes que não ferroviário "stricto sensu". Assim, inicialmente o transporte urbano, através de bondes, passou a ser regulado por este dispositivo legal.

Em seguida todo o transporte rodoviário passou a ser considerado pela jurisprudência como regulado pela lei 2681.

Este passo, a princípio temeroso, após decidido, representou um grande avanço na solução do problema que mais e mais surgia ante os tribunais.

$\mathrm{Na}$ falta de um dispositivo próprio, as normas contidas na lei 2.681 eram suficientes no preenchimento de uma gritante lacuna legislativa.

Porém, é evidente, como solução definitiva não pode ser aceita esta extensão. Ocorre que as carta nod um e outro tipo de transporte meiro - transporte ferroviário - em casos de acidente oferece, indubitavelmente uma maior segurança ao passageiro do que o segundo, além de estarem os veículos ferroviários menos sujeitos a abalroamentos do que os rodoviários. Assim os acidentes e os danos daí gerados terão sempre características diversas, e a unidade de solução, se satisfaz em razão do preenchimento de uma lacuna, não pode satisfazer em todos os aspectos.

Deve ser entendida como uma solução temporária e nunca como solução definitiva este entendimento jurisprudencial.

Outro aspecto bastante discutido nos tribunais é o de se saber se a culpa concorrente do passageiro permitiria a divisão da responsabilidade.

Concluiu a maioria de nossa jursiprudência pela impossibilidade, uma vez que a participação do passageiro no desastre era sempre, ou quase sempre, mínima e pouco in fluente no resultado final.

Exemplo disto é o acórdão da lavra do Min. Ribeiro da Costa, in DJ de 03.08.59, a pág. 2645/7:

"Quando se enfrenta acidente de que é vítima passageiro de trem, reconhece-se indistintamente a culpa presumida da emprêsa responsável ainda que tenha admitido o passageiro como "pingente", circunstância que não a subtrai de qualquer parcela de responsabilidade, porque prepondera aquela presunção que inteiramente absorve, ainda que provada, a culpa concorrente da vítima, pois despe-se esta de mínima influência na relação obrigacional constituída pelo contrato de adesão, em face do responsável".

Todos estes aspectos, como se nota, são característicos de um transporte específico, qual seja o transporte ferroviário. No caso do transporte rodoviário pode-se imaginar, sem esforco especial, outras situacões, em que a atitude da vítima pode ser, até, a causa direta do acidente.

Outra solução ofertada pela jurisprudência, e de muita importância para a definição total do assunto, é a de que a culpa de terceiro não elide a responsabilidade civil do transportador.

Este entendimento ficou consubstanciado com a súmula 187 do Supremo Tribunal Federal:

"A responsabilidade contratual do transportador, pelo acidente com o passageiro, não é elidida por culpa de terceiro, contra o qual tem ação regressiva".

Com isso, deu-se grande passo à consagração da teoria do risco, porém sempre com a ressalva da responsabilidade contratual. 
Insistimos: será apenas em relação ao passageiro que mantém um contrato de transporte válido que se aplica a responsabilidade sem culpa, ou ela também pode se aplicar a todos os casos de acidentes que causem danos às pessoas transportadas? o contrato ou o fato do transporte que ermina a incidência da teoria do risco?

Pela interpretação não extensiva da Súmula 182, aplica-se a responsabilidade sem culpa apenas aqueles com quem a transportadora mantém contrato de transporte, eis que e cogita apenas de responsabilidade contratual.

Entretanto, como vimos, a distinção entre responsabilidade contratual e aquiliana, em nossa opinião, não representa maior diferença, eis que se diferencia da responsabilidade extra-cantratual apenas quanto à origem. Pode-se interpretar a Súmula 187 no sentido de ser aplicada a do o passageiro, independentemente de haver ou não contrato de transporte.

Estes os aspectos de maior relêvo discutidos nos tribunais em relação ao assunto em estudo. Outras conclusõe contribuiram para a definição do problema, principalmente na determinação das situações de fato que caracterizam força maior ou caso fortuito que, como já referimos, formaram grandes discussões, permitidas pela lei, neste particular esquecida da teoria do risco.

Pode-se concluir que a jurisprudência contribuiu, decisivamente, para a crescente implantação da teoria do risco em nosso meio, a respeito de transporte.

Fixou a diferença, atualmente existente entre os danos causados ao passageiro e a terceiros, baseando-se na distinção de responsabilidade contratual e extra-contratual, conseguindo, desta forma, um certo equilíbrio,contratual, condesastrosos efeitos de uma aplicação, sem preca teoria do risco.

Veremos adiante como a teoria do risco só pode ser adotada conjuntamente com outras medidas que pode ser adodesequilíbrion que evitem outro de determinar centas medidas, sentiram os julgadores a inconveniência de uma aplicação total da teoria do risco, e utilizaram-se da distinção entre responsabilidade contratual e extra-contratual para restringir a sua aplicação.

Se foi um erro no sentido técnico foi um acerto do ponto de vista de equilíbrio social.

\section{O ALCANCE DA INDENIZACX̃o}

Atingimos, a esta altura, o exame de um aspecto que apresenta vital importância dentro do estudo do tema a que nos propusemos.

Como vimos, a criação e mesmo toda a evolucão da responsabilidade civil baseou-se na preocupação, a início individual e após estatal de recuperar um equilíbrio perdido em função de um dano gerado.

Como toda a forca propulsora de algo não ocorrendo sua desaceleração, uma vez atingido o objetivo a que se propos, a preocupação em manter um equilíbrio social rompido extravasou de suas finalidades, passando a causar, amiude, outro tipo de desequilíbrio.

A preocupação de proporcionar à vítima, ou seus beneficiários, as mesmas condições econômicas que desfrutavam antes do dano, terminou por sacrificar, em alguns casos, em demasia ao ofensor.

Realmente a princípio tímido e agora francamente entenderam os tribunais em estender ao máximo o alcance da indenização, causando, não raro, uma melhoria nas condicões econômicas do ofendido (ou seus beneficiários)

E evidente, e a ressalva cabe, que não se cogita de argumentar no sentido de que a melhoria de vida supre em caso de acidentes fatais ou graves, as conseqüências do dano. Trata-se da necessidade de adoção de critérios menos amplos, independentemente da relação de igualdade entre o dano e a indenização.

Se é verdade que desde o Direito Romano entendeu-se que a reparação econômica do dano é a melhor medida de equilíbrio, nem porisso é indispensável a igualdade.

Exemplo disto - melhoria na situação econômica da vítima ou beneficiários - é o entendimento consagrado pela jurisprudência de que não é abatível da pensão devida pelo ofensor a quantia recebida pela vítima ou beneficiários de órgãos previdenciários, ou mesmo particulares. A partir daí, por exemplo em caso de morte, os beneficiários passam a perceber o valor da pensão previdenciária e mais a pensão pelo ofendido, calculada sobre o percebimento normal da vítima, de onde se deduzem, tão somente, os seus gastos particulares.

Esta situação teve origem no desejo dos julgadores de compensar a perda da vida ou redução da capacidade de trabalho por parte do infortunado. 
Da mesma natureza outros entendimentos que favorecem a vítima ou seus beneficiários, todos tendentes à ampliação da pensão.

Esta preocupação, se salutar em princípio, tem gerado distorções indesejáveis e condenáveis.

Veja-se o caso das transportadoras de pessoas, que são os responsáveis maís frequientes em ações de indenizacões.

Conta a vítima com as consequiências, por sinal justas da quase aplicação da teoria do risco. Com isso está liberada de provar culpa do ofensor. De outro lado tem toda a proteção jurisprudencial no sentido da fixação da mai ampla indenização possível.

Não é levado em conta o problema da transportadora: se de um lado tem a consciência de que deve arcar com os riscos da exploração de seu negócio, não se pode esquecer que está a mesma desempenhando um serviço de utilidade pública, qual seja o de transporte de passageiros.

Assim, além da desvantagem que lhe advem da adoção da responsabilidade sem culpa, sofrem as mesmas pesados ônus em face das largas pensões fixadas que, não raro, chegam a prejudicar a sua posição financeira.

O princípio de que a indenização deva ser a mais ampla possível deve ser examinado à luz da realidade.

Não se pode, em nome da manutenção de um equilíbrio social, prejudicar, como vem acontecendo, todo um sistema de prestação de serviços. Não pode ter tão largo alcance a indenização, nos casos de emprêsas de transporte, sob pena de ficar comprometido todo um esquema de transporte rodoviário de pessoas.

Ver-se-á com maior profundidade, adiante, com a aplicação da teoria do risco poderá ter caráter mais dinâmico e geral, contribuindo assim para a mais ré mais dinâmico pendências a este respeito pua solução das acontece em relação ao transporte aéreo, da fixação de jimite para a indenização, o que permite, por parte da emprêsa rodoviária responsável, a adoção de medidas internas que contornem este problema, adequando-se econômico-financeiramente a ele.

\section{A EMPRESA DE TRANSPORTE RODOVIARIO COLETIVO DE PASSAGEIROS \\ CAPITULO VIII}

\section{A CONCESSão de SERViço Público}

Após tratarmos da responsabilidade civil, em seus aspectos genéricos, embora sempre tendo em mente o específico do tema, entendemos conveniente e elucidadora uma apresentação das emprêsas rodoviárias naquilo que diz mais de perto ao assunto.

Como é de conhecimento geral as transportadoras rodoviárias atuam na qualidade de concessionárias de serviço público.

Estas concessões são reguladas em diferentes dispositivos legais, conforme a subordinação das emprêsas a órgãos municipais, estaduais ou federais.

No plano federal as concessões e permissões estão a cargo do Departamento Nacional de Estradas de Rodagem, de acordo com o disposto no art. 24, parágrafo único, do decreto-lei $n^{\circ} 312$ de 21 de março de 1969 que assim dispõe:

"Parágrafo único: Enquanto não for criado tal órgão, os serviços de concessão, permissão e fiscalização do transporte de passageiros e de carga continuarão a cargo do Departamento Nacional de Estradas de Rodagem, na forma da legislação vigente".

Assim o transporte coletivo de passageiros de caráter interestadual ou internacional foi regulado pelo decreto $\mathrm{n}^{\mathbf{0}}$ 68.961 de 20 de julho de 1971 .

São de interêsse e repercussão em nosso estudo alguns aspectos legislativos, na medida em que fixam exigências para as transportadoras que entram em choque ou são dificultadas pelo probema da apicação da teoria do risco sem fixação de limites indenizatórios.

E exemplo disto o que dispõe o art. $4^{\circ}$ do citado diploma:

"A outorga de concessão ou de autorização para execução dos serviços proceder-se-á visando ao interesse público nos têrmos deste regulamento.

Parágrafo único: A oportunidade e conveniência do serviço, para efeito de outorga de concessão, serão apurados pelo exame conjunto dos seguintes fatores principais:

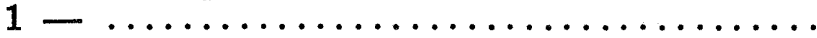

II - possibilidade de exploração economica- 
mente suficiente, aferida pelo coeficiente de utilização adotado na composição tarifária.

III $-\ldots \ldots \ldots \ldots \ldots \ldots \ldots \ldots \ldots \ldots \ldots \ldots \ldots$

Veja-se, assim, a repercussão enorme, no próprio desenvolvimento da empresa, de sua adequação econômico-financeira.

Outro aspecto interessante é a fixação tanto no plano federal, através do dec. 68.691, como em alguns estados entre os quais o Rio Grande do Sul, de limite para a indenização relativa a danos causados às bagagens dos passageiros. Assim dispõe o decreto sobre a matéria:

"Art. $33-\S 1$ - As transportadoras só serão responsáveis pelo extravio dos volumes transportados nas bagageiras, sob comprovante, até o limite do valor fixado no item II deste artigo. (2 salários-mínimos de maior valor no país)".

Desta forma, em assunto muito menos reflexivo na economia da emprêsa, foi fixado um limite, dada a impossibilidade das empresas de atender às postulações e pretensões das pessoas prejudicadas, sem a possibilidade de previsão.

Segue, outrossim, tanto este decreto, como qualquer outro dispositivo legal brasileiro, na omissão total a respeito da responsabilidade civil por danos pessoais, mantendo-se assim no Brasil um problema já solucionando em outros países.

Cumpre ainda notar o restante das disposições legislativas e administrativas, bastante exigentes e rigorosas para com as transportadoras.

Todo este conjunto é apresentado para demonstrar a série de ônus e encargos que têm as empresas rodoviárias, na exploração de suas concessões. Aliando-se estas exigências à exiguidade da composição tarifária, como adiante veremos um pequeno pano de amostra da impossibilidade de crer, na dimensão em que hoje é tratado o assunto, com as indenizações fixadas pelo Judiciário.

\section{CAPfTULO IV}

\section{DADOS ESTATISTICOS}

Embora a natureza do presente trabalho, não podemos deixar de situar o leitor, em termos de números relativos a empresas de transporte rodoviário, que se revelarão impressionantes.
Estes dados demonstram a situação de fato, instrumento poderoso na mão do jurista eis que é ela, em última análise, o fim do mesmo de direito.

Esquecendo-se a realidade dos fatos, além de tornarmos a ciência jurídica irreal e inócua, estaremos evitando que o direito se atualize e regre com maior eficiência a realidade social.

Os dados que a seguir revelaremos foram fornecidos pelo Departamento Autônomo de Estradas de Rodagem DAER - do Rio Grande do Sul, numa gentileza dos membros de sua Diretoria de Tráfego, aos quais manifestamos nosso agradecimento.

Estes dados revelam que, efetivamente, o transporte rodoviário está a merecer um regime especial, não só quanto às relaçóes das empresas com o respectivo poder concedente mas também quanto as suas relações com os usuários, principalmente no assunto de que tratamos, já se constituindo o transporte rodoviário no mais importante transporte de massa no Brasil.

No Rio Grande do Sul, em 1970, existiam 232 empresas de transporte intermunicipal de passageiros, número que, em 1972, passou a 234, o que revela progresso, eis que a proliferação demasiada de transportadoras não é recomendada pelos técnicos, sendo preferível a concentração dos serviços em um menor número de empresas, o que ocasionaria uma redução geral do custo operacional.

Estas empresas percorreram em 1970 a astronômica cifra de 116.628.758 quilômetros, o que equivale, aproximadamente, a 9.100 vezes o diâmetro da Terra. E note-se que isto é apenas no Rio Grande do Sul e que se refere apenas as empresas que exploram as linhas intermunicipais, não estando computadas as quilometragens realizadas pelas empresas de âmbito municipal, nem pelas empresas interestaduais ou internacionais.

Neste mesmo ano, foram transportados 98.229.627 passageiros, ou seja, mais do que a população brasileira na época. Os dados referem-se igualmente apenas a empresas intermunicipais.

Já dois anos após, ou seja, em 1973 os dados revelam um aumento espantoso. Percorreram as empresas ...... 166.836.755 quilômetros. Esta rodagem equivale a 13.000 vezes o diâmetro da Terra.

Neste mesmo ano foram transportados 132.562 .777 passageiros.

Estes números enfatizam a importância do transporte de passageiros por via rodoviária. 
Esta importância dupla, ou seja, do transporte de pessoas dentro da responsabilidade civil e do transporte rodoviário dentro dos transportes, estão a exigir uma regulamentação própria.

Não se pode entender como o mais importante aspecto de um problema não tenha regime próprio, quando os menos importantes estão devida e corretamente regulados.

\section{CAPfTULO $\mathrm{X}$}

\section{O REGIME TARIFARIO}

O último aspecto, em relação às transportadoras rodoviárias, que entendemos de interesse para a solução do problema da responsabilidade civil, é a composição tarifária.

Estes elementos, a seguir rapidamente analisados, darnos-ão os dados finais para a conclusão deste pequeno estudo.

sabido que a tarifa de transporte rodoviário, contraprestação do passageiro em relação ao contrato de transporte, não é fixada pela transportadora e sim pelo poder público, em nossos dias pelo Conselho Interministerial de Preços - CIP - , relacionada sempre aos custos do transporte.

A rentabilidade fixada pelo poder público é extremamente inferior a de qualquer indústria ou a de qualquer atividade comercial.

Segundo ainda dados fornecidos pelo DAER atualmente a rentabilidade das empresas é fixada em termos de $12 \%$ ao ano. Esta baixa rentabilidade tem sua fundamentação no fato de que o transporte é feito mediante concessão, que representa ao transportador uma parcela de segurança inexistente em outro tipo de exploração econômica.

Consequiência disto é que o transportador não pode sobreviver sem um perfeito sistema de previsão de despesas e de aplicação de receita em novos investimentos. Todo o gasto deve ser previsível e adequado à economia da empresa.

Apenas com finalidade ilustrativa e para confirmar que se afirmou acima, transcrevemos a fórmula e seus elementos utilizados para o cálculo tarifário:

$$
R_{k}=\frac{068 \times 0,12 \times V}{K}
$$

sendo que:
$0,68=$ coeficiente obtido admitindo uma frota composta de $60 \%$ de veículos com idade média de 2,5 anos e $20 \%$ com idade zero.

$\mathbf{0 , 1 2}=$ taxa correspondente a remuneração de capital (12\% ao ano).

$\mathrm{V}=$ valor do veículo novo

$\mathrm{K}=$ rodagem média anual por veículo

Assim entendemos ter ficado demonstrado como a fixacão da tarifa é mais um elemento de fato a determinar reflexos no problema da responsabilidade civil.

Nenhuma empresa, sem sacrificar o seu próprio e o desenvolvimento de todo o sistema de transporte, poderá suportar o risco de sua atividade sem outra medida - limitação de responsabilidade civil — sob pena de sucumbir, causando graves consequências neste importante setor da economia nacional.

\section{CONCLUSõES}

\section{CAPITULO XI}

\section{A NECESSIDADE DA LIMITAÇÃO DA RESPONSABILIDADE}

Após verificarmos, no plano teórico, qual o fundamento da responsabilidade civil, examinamos os dispositivos legais vigentes no Brasil e as soluções apresentadas pela jurisprudência; após destacarmos os principais problemas da responsabilidade civil; após a apresentação mesmo sumária das empresas de transporte; sentimos, globalmente, a importância da questão da limitação da responsabilidade.

Todos os caminhos apontam nesta direção:

Não pode restar dúvida quanto à importância do transporte rodoviário como meio de comunicacão sócio-econômica. Os números trazidos bem demonstram a utilização desca. Os numeros trazidos

Desta maneira cresce a importância social da empresa que explora esta atividade, eis que representa a garantia de funcionamento da mesma.

evidente que estão muito mais sujeitas a problemas de responsabilidade civil por danos pessoais, não por ser perigosa a atividade, mas pelo fato de que em estradas são inevitáveis os acidentes, apesar de todas as precauções tomadas preventivamente.

Assim, basta um rápido olhar para os repertórios de jurisprudência para encontrarmos, como partes, as empresas de transporte rodoviário. 
Desta forma seus problemas transcendem sua órbita de interesses: também ao Estado deve interessar o problema aqui levantado, eis que das empresas depende o transporte.

Esta realidade de fato, entretanto, inexplicavelmente, ainda não foi regrada convenientemente.

Deixou-se à jurisprudência a tarefa de encontrar dispositivos que pudesse aplicar, sanando esta lacuna legislativa. Porém não é suficiente esta solução provisória: a realidade está a clamar por um regramento específico.

A afirmação é tão certa quanto grande tem sido a tarefa jurisprudencial em resolver, adequadamente, os problemas que amiude lhe são apresentados.

E o que mais chama a atenção é o fato de que outros tipos de transporte, mais recentes, desenvolveram-se extraordinariamente, sem que o transporte rodoviário o acompanhasse. A razão que se pode encontrar para este fato, principalmente em relação ao transporte aéreo, é a de que as convenções internacionais sobre direito aeronáutico são muito mais frequientes do que as relativas a direito rodoviário.

Já há, hoje em dia, ainda nos terrenos dos estudos, uma convenção internacional sobre transporte de passageiros. a "Convention relative au contrat de transport international de voyageurs et des bagages par route - CVR".

"Le transporteur est responseble du préjudica résultant de la mort, des blessures ou de teutes autres atteintes à la intégrité physique ou mentale causées au voyageur par un accident en relation avec le transport et survenent pendent que le dit voyageur se trouve dans le vehicule ou pendent qu'il y entre ou qu'il en sort, ou survenant du fait du chargement ou du déchargement des bagages.

Le transporteur est déchargé de cette responsabilité si l'accident a eu pour cause des circonstances qu'un transporteur, en dépit de la diligence requise d'aprés les particularités de l'espèce ne pouvait pas éviter et aux consequences desquelles il ne pouvait pas obvier'"

Como se vê, trata-se da aplicação da teoria da culpa, uma vez que se desonera o transportador quando demonstra que o acidente não poderia ser avitado, empregada toda a ediligência possível.

Já se nota a grande dificuldade em determinar a suficiência ou não das medidas de segurança empregadas pelo transportador, em cada caso.
Soluções como essa é que entravam a pronta reparação da vítima, fazendo com que os processos de indenização permaneçam anos e anos sem resposta adequada.

Mais adiante, a CVR ameniza bastante o erro cometido quando exclui determinados fatos do rol de justificativas do transportador. E o velho sistema de, adotada a teoria da culpa, amenizar seus efeitos, procurando uma solução que contorne os problemas gerados. Assim, é vedado ao transportador, alegar em sua defesa falhas psíquicas ou mentais do motorista, defeitos ou mau funcioanmento do veículo.

Entretanto, a culpa de terceiros é excludente da responsabilidade do transportador segundo o sistema da convenção, o que gera toda a discussão sobre a "culpa" no acidente, atrasando-o bastante, quando poderia ter o mesmo uma solução rápida.

O próprio Brasil, que não dispõe de texto específico sobre a matéria, evitou o problema da culpa de terceiros, através de construcão jurisprudencial, consubstanciada, como vimos, na Súmula 187.

Vê-se portanto que a técnica adotada pela CVR é totalmente superada, representando um atraso e nunca uma evolução neste setor.

Entretanto, mesmo sendo desatualizada, contém a convenção a regra que o Brasil, com todo o desenvolvimento do assunto teve ainda: a limitação da responsabilidade:

"Article 13 - Le montant total des dommages-intérêts è payer par le transporteur pour un même événement ne peut déspesser 250.00 francs per victime".

Pode-se verificar então que a ausência de um dispositivo legal que limite a indenização, em matéria de transporte, é falha séria, já que é medida comum em todos outros países.

$\mathrm{E}$, efetivamente, podemos com segurança afirmar que, se de um lado a teoria do risco é o sistema mais dinâmico, propiciando rápidas soluções judiciais e adaptando-se a uma realidade social cada dia mais exigente, não é menos verdade que não pode ser aplicada em toda a sua extensão sem o dispositivo. A fixação do limite indenizatório compõe a própria teoria do risco e sem ela, como dissemos o equilíbrio restaurado num aspecto gera desequilíbrio noutro.

Porisso enquanto inexistir tal limite somos forçados a adotar uma teoria mista.

Em relação ao passageiro, por estar subordinado às determinações do transportador e em sua área de ação, in- 
dependente de ter contratado validamente ou não com ele, pode-se adotar a teoria do risco, pela qual é o transportador responsável pelo dano causado, exceto em caso de culpa da vítima.

Porém, em relação ao terceiro não passageiro, enquanto não existir o limite que é pressuposto quase de aplicação da responsabilidade sem culpa nestes casos, ter-se-á que recorrer à teoria da culpa. Mesmo que se adote a presuncão de culpa haverá de ser permitida a prova em contrário da existência da mesma. Não é uma solução definitiva e é válida até que se entenda limitar a responsabilidade do transportador, com o que se terá dado passo gigantesco, eis que então a aplicação da responsabilidade sem culpa poderá ser total e indiscriminado.

Enquanto permanecermos presos a idéias antiquadas não veremos prosperar o direito: este necessita de idéias modernas e realistas, coerentes com as situações de fato do dia a dia.

Temos certeza de que quando esta realidade for encarada com a seriedade que merce, as soluções serão mais rápidas e eficientes, mais justas e equânimes, e o caminho para isso, temos certeza, será o indicado neste trabalho, ou seja, a limitação do valor da indenização para estes casos específicos.

\section{BIBLIOGRAFIA}

- A. CARDOSO DE GUSMÃO JR. "A indenização nos acidentes pessoais"

- ADAUTO FERNANDES. "Cláusula de não responsabilidade"

- ALVINO LIMA. "Da culpa ao risco" in. Rev. Forense vol. 83 pág. 386

- CARVALHO AZEREDO. "A indenização por ato ilícito"

- CAMILLE JAUFFRET. "La responsabilité civile en matière d'accidents d'automobiles"

- G. P. CHIRONI. "Le colpa nel diritto civile odierno"

- HANS ALBRECHT FISCHEN. "Reparação dos danos"

- HENRI LALOU. "Traité pratique dela responsabilité civile"

- J. MOSSET ITURRASPE. "Responsabilidad por daños" - JOSE DE AGUIAR DIAS. "De responsabilidade civil"

- JOSE DE AGUIAR DIAS. "Cláusula de não indenizar"

- OLIVEIRA E SILVA. "Desindenizações por acidentes"

- PEDRO BAPTISTA MARTINS. "O abuso do direito e o ato ilícito"
- PONTES DE MIRANDA. "Tratado de direito privado" vols. 45,53 e 54

- RENÉ SAVATIER. "Traité de la responsabilité civile en droit français"

- VIEIRA FERREIRA. "Responsabilidade civil em acidentes de automóvel" 